\title{
PENGARUH PEMBERIAN SARI DAUN CINCAU HIJAU (PREMNA OBLONGIFOLIA MERR) TERHADAP KADAR KOLESTEROL HDL DAN KOLESTEROL LDL TIKUS SPRAGUE DAWLEY DISLIPIDEMIA
}

\author{
Ananda Eka Astirani, Hesti Murwani $\mathbf{R}^{*}$ \\ Program Studi Ilmu Gizi Fakultas Kedokteran Universitas Diponegoro \\ Jl.Dr.Sutomo No.14, Semarang, Telp (024) 8453708, Email : gizifk@undip.ac.id
}

\begin{abstract}
Background : Dyslipidemia is an increase in total cholesterol, LDL-cholesterol and triglycerides and also decrease HDL-cholesterol concentration from normal range. Restricting fat consumption, increasing intake of fruits and vegetables rich in fiber and antioxidant can help manage dyslipidemia. Green grass jelly (Premna oblongifolia Merr) rich in fiber and chlorophyll which can increase HDL-cholesterol and decrease LDL cholesterol.

Objective : to analyze the effect of green grass jelly extract on HDL-cholesterol and LDL-cholesterol alteration.

Methods : This research was experimental laboratory using pre-post test with randomized control groups design. Sample were male Sprague Dawley rats, 7-8 weeks old, inducted dyslipidemia, given green grass jelly diet using 2,7 $\mathrm{ml}$ and 5,4 $\mathrm{ml}$ dosage for 28 days. HDL-cholesterol and LDL-cholesterol were measured by CHOD-PAP and diasis reagent. Normality data were tested by Saphiro Wilk test. Data were analyzed by paired t test/wilcoxon and Anoval Kruskal wallis.

Result : Green grass jelly (Premna oblongifolia Merr) extract 5,4 ml/day can significantly increase HDL-

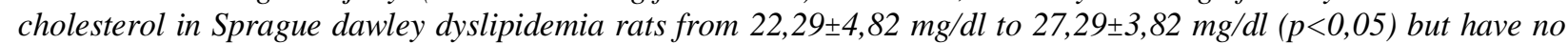
effect for decreasing LDL-cholesterol serum.

Conclusion : Green grass jelly (Premna oblongifolia Merr) extract 5,4 ml/day can significantly increase HDLcholesterol in Sprague dawley dyslipidemia rats for about $22 \%$.
\end{abstract}

Keywords : green grass jelly; HDL cholesterol; LDL cholesterol; dyslipidemia

\begin{abstract}
ABSTRAK
Latar Belakang : Dislipidemia merupakan peningkatan kadar kolesterol total, kolesterol LDL, dan trigliserida serta penurunan kolesterol HDL serum dari batas normal. Mengurangi konsumsi lemak, meningkatkan asupan sayur dan buah yang kaya serat dan antioksidan dapat membantu mengontrol dislipidemia. Daun cincau hijau (Premna oblongifolia Merr) kaya serat dan klorofil yang diduga mampu meningkatkan kadar kolesterol HDL dan menurunkan kadar kolesterol LDL.

Tujuan : Menganalisis pengaruh pemberian sari daun cincau hijau terhadap perubahan kadar kolesterol HDL dan kolesterol LDL.

Metode : Penelitian ini merupakan penelitian experimental laboratorik jenis randomized control groups pre-post design. Sampel adalah tikus jantan galur Sprague Dawley umur 7-8 minggu dislipidemia, diberi sari daun cincau hijau sebanyak 2,7 ml dan 5,4 ml selama 28 hari. Kolesterol HDL dan kolesterol LDL diukur dengan menggunakan metode CHOD-PAP dan reagen diasis. Normalitas data diuji dengan Saphiro Wilk. Data dianalisis menggunakan uji paired t test/ wilcoxon dan Anova/Kruskal Wallis.

Hasil : Pemberian sari daun cincau hijau dengan dosis 5,4 ml pada tikus mampu meningkatkan kadar kolesterol

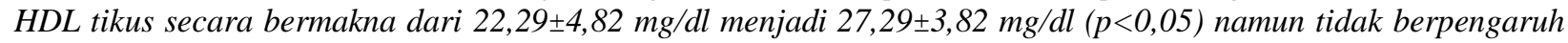
terhadap penurunan kadar kolesterol LDL.

Kesimpulan : Sari daun cincau hijau 5,4 ml/hari yang diberikan selama 28 hari mampu meningkatkan kadar kolesterol HDL tikus Sprague dawley dislipidemia secara bermakna sekitar $22 \%$.
\end{abstract}

Kata Kunci : cincau hijau; kolesterol HDL; kolesterol LDL; dislipidemia

\section{PENDAHULUAN}

Dislipidemia merupakan keadaan yang ditandai dengan peningkatan kadar kolesterol total, kolesterol LDL, dan trigliserida serta penurunan kadar kolesterol HDL serum dari batas normal. ${ }^{1}$ Pola makan tinggi kolesterol, asam lemak jenuh dan intensitas makan yang tinggi menyebabkan kadar kolesterol sulit dikontrol. ${ }^{2}$ Penderita dislipidemia memiliki risiko lebih tinggi terkena penyakit kardiovaskuler. $^{3}$

Diet rendah lemak dan kolesterol, olahraga teratur, pengendalian berat badan dan terapi farmakologi merupakan cara yang dapat dilakukan untuk menurunkan kadar kolesterol darah yang

${ }^{*}$ Penulis Penanggungjawab 
tinggi serta meningkatkan kadar kolesterol HDL. ${ }^{6}$ Pengaturan pola diet yang dapat dilakukan untuk menurunkan kadar kolesterol adalah dengan mengurangi konsumsi lemak dan meningkatkan asupan sayur dan buah yang kaya serat dan antioksidan.

Cincau hijau (Premna oblongifolia Merr) merupakan tanaman sebagai bahan pembuatan minuman yang bersifat mudah menjadi gel. $^{7}$ Penelitian mengenai pemanfaatan ekstrak klorofil daun cincau hijau terhadap penurunan profil lipid kelinci sudah pernah dilakukan. Hasilnya menunjukan bahwa ekstrak klorofil daun cincau hijau mampu menurunkan kadar kolesterol total dan trigliserid secara signifikan, meningkatkan kadar kolesterol HDL, sedangkan untuk kadar kolesterol LDL tidak mengalami penurunan secara signifikan. ${ }^{8}$

Komponen utama cincau hijau yang membentuk gel adalah polisakarida pektin. ${ }^{9}$ Pektin termasuk jenis serat pangan larut air dan mudah difermentasi oleh mikroflora usus besar. ${ }^{10} \mathrm{Di}$ dalam saluran pencernaan, serat larut air mengikat asam empedu yang merupakan produk akhir dari kolesterol dan kemudian dikeluarkan bersama feses. Hal tersebut yang diduga dapat menyebabkan terjadinya penurunan kadar kolesterol di dalam tubuh.

Selain serat, kandungan klorofil yang terdapat pada cincau hijau cukup tinggi jika dibandingkan dengan daun tanaman lain seperti kemangi, kangkung, bayam, dan pegagan. ${ }^{11}$ Struktur klorofil terdiri dari dua bagian yaitu cincin kompleks porfirin dan fitol. Fitol bersifat hidrofobik yang dapat menyebabkan penurunan timbunan lemak dalam darah sekaligus mencegah penyumbatan pembuluh darah. Pada klorofil juga terdapat fitokimia saponin yang diketahui dapat mengikat dan mencegah penyerapan kolesterol. ${ }^{12}$

Berdasarkan latar belakang tersebut, maka peneliti ingin mengkaji pengaruh pemberian sari daun cincau hijau terhadap kadar kolesterol HDL dan kolesterol LDL tikus sprague dawley dislipidemia. Tikus dipilih sebagai subjek dalam penelitian ini karena memiliki sifat lebih tahan terhadap perlakuan, omnivora, tidak dapat muntah, memiliki kemiripan fisiologis dengan manusia dibandingkan dengan hewan lain, selain itu juga dapat dilakukan kontrol dari segi asupan makanan untuk menghindari adanya bias pada hasil penelitian.

\section{METODE PENELITIAN}

Penelitian yang dilakukan di Laboratorium Fisiologi Hewan Fakultas Matematika dan Ilmu Pengetahuan Alam Universitas Negeri Semarang ini merupakan penelitian experimental laboratorik jenis randomized control groups pre-post design. ${ }^{13}$ Perlakuannya adalah dengan pemberian sari daun cincau hijau (Premna oblongifolia Merr) berbagai dosis. Setiap hari dilakukan penimbangan berat badan tikus dan sisa pakan. Hasil akhir yang dianalisis dalam penelitian ini adalah kadar kolesterol HDL dan kolesterol LDL.

Sampel penelitian adalah tikus jantan galur Sprague Dawley umur 7-8 minggu yang diperoleh dari Laboratorium Farmasi Universitas Gajah Mada, Yogyakarta. Besar sampel minimal dalam penelitian ini yaitu 6 ekor yang ditentukan berdasarkan rumus Federer ${ }^{14}$. Pada penelitian ini menggunakan 7 ekor tikus untuk setiap kelompok perlakuan untuk mengantisipasi drop out. Kelompok pada penelitian ini terdiri dari kontrol negatif, kontrol positif, kelompok perlakuan 1 dosis $2,7 \mathrm{ml}$, dan kelompok perlakuan 2 dosis 5,4 $\mathrm{ml}$ sehingga jumlah tikus yang digunakan adalah 28 ekor. Dosis cincau hijau yang diberikan didasarkan pada konversi dosis cincau hijau dari manusia yaitu sebesar $150 \mathrm{~g}$ ke tikus dengan berat badan $200 \mathrm{~g} .{ }^{15,16}$ Sari daun cincau hijau diberikan menggunakan sonde.

Seluruh sampel diadaptasi selama 7 hari dengan menggunakan pakan standar dan minum $a d$ libithum. Kelompok kontrol negatif tetap diberi pakan standar sampai akhir penelitian sedangkan kelompok kontrol positif dan kelompok perlakuan diberikan pakan tinggi kolesterol selama 28 hari untuk membuat tikus menjadi dislipidemia. Pakan tinggi kolesterol dibuat dengan cara menambahkan pakan standar dengan kuning telur sebanyak $10 \%{ }^{18}$ Sari daun cincau hijau yang digunakan berasal dari daun cincau hijau perdu (Premna oblongifolia Merr). Daun cincau kemudian diambil sarinya dengan cara meremas daun yang ditambah air demineralisasi dengan perbandingan 1:1.

Profil lipid awal adalah kadar profil lipid setelah pemberian pakan tinggi kolesterol selama 28 hari. Profil lipid akhir tikus adalah profil lipid setelah pemberian sari daun cincau hijau selama 28 hari. ${ }^{8}$ Sampel darah diambil sebanyak $2 \mathrm{ml}$ melalui pleksus retroorbitalis. ${ }^{17}$ Kadar kolesterol HDL tikus diperiksa dengan metode CHOD-PAP dan kolesterol LDL menggunakan reagen diasis.

Data yang diperoleh diolah dengan program komputer. Data tersebut diuji normalitasnya dengan uji Saphiro Wilk kemudian 
dianalisis menggunakan paired t-test/wilcoxon dan Anova/Kruskal Wallis.. ${ }^{14}$

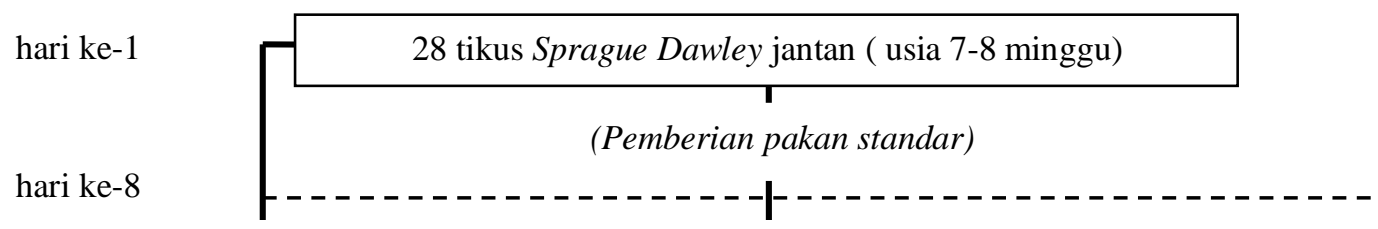

(Pemberian pakan standar)

(Pemberian pakan tinggi kolesterol)

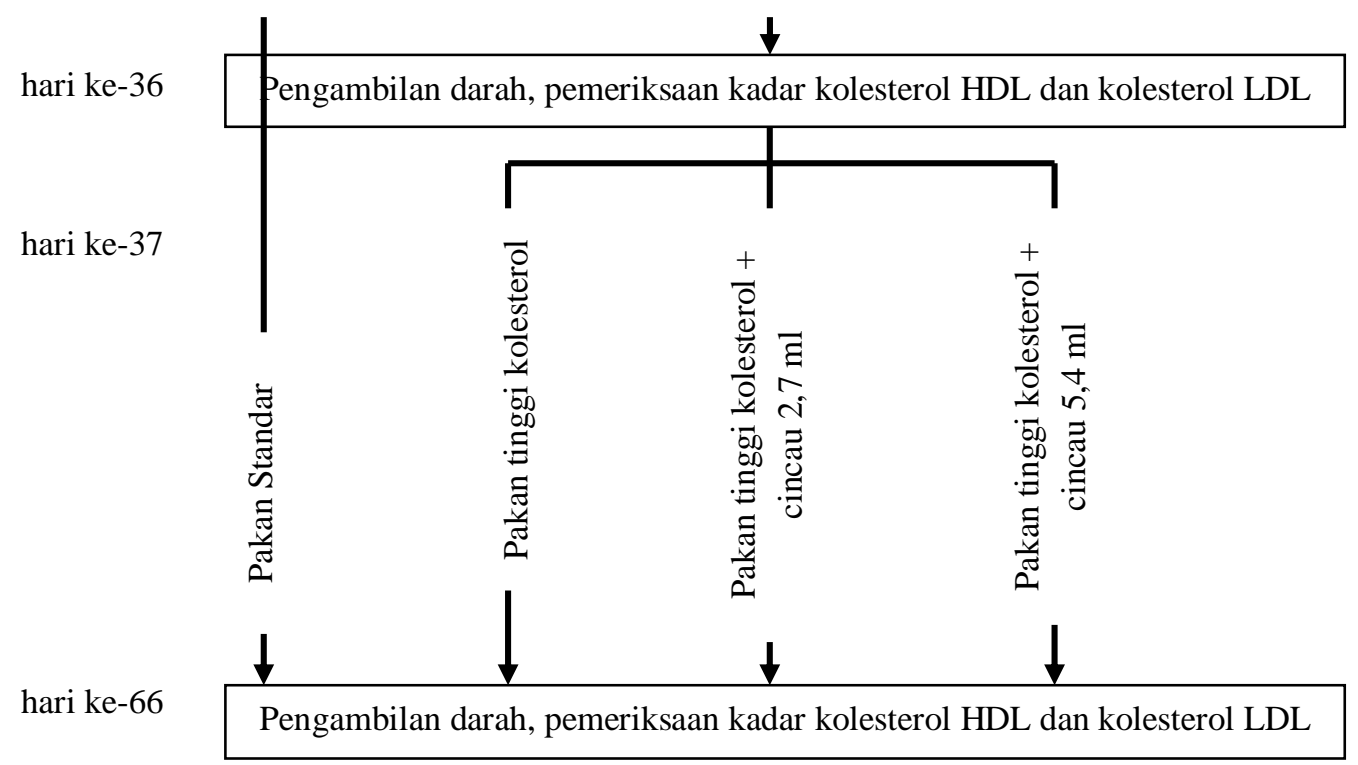

Gambar 1. Alur Penelitian

HASIL PENELITIAN

Karakteristik Sampel
Sampel adalah tikus Sprague dawley jantan dislipidemia usia 7-8 minggu dengan berat badan berkisar antara 100-250 g.

\section{Asupan Makan dan Berat Badan Sampel}

Tabel 1. Hasil Analisis Bivariat Rerata Asupan Makan

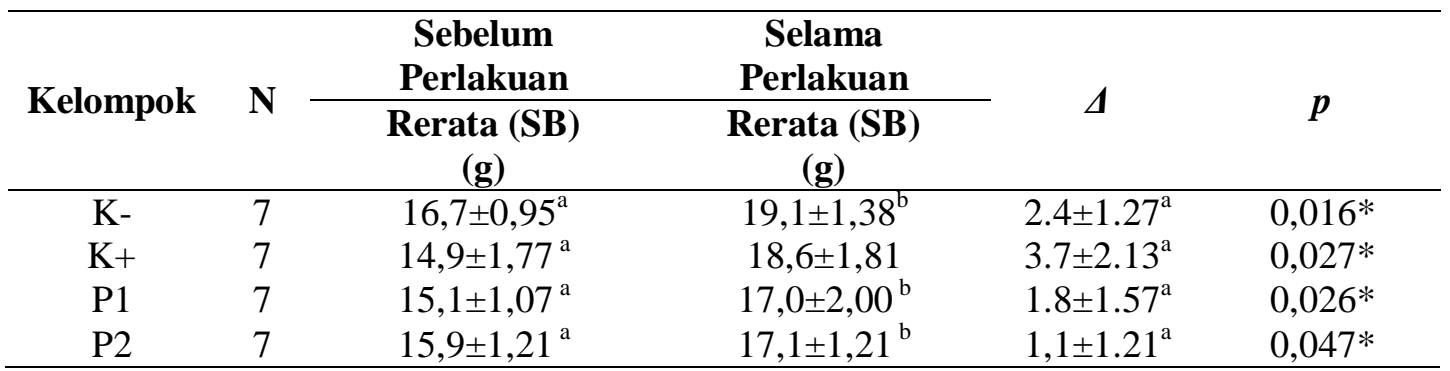

${ }^{a}$ uji beda Kruskal Wallis (p>0,05)

${ }^{\mathrm{b}}$ uji Mann-Whitney $(\mathrm{p}<0,05)$

*beda bermakna

Keterangan : K- : kelompok kontrol negatif

$\mathrm{K}+$ :kelompok kontrol positif

P1 : kelompok perlakuan sari daun cincau hijau 2,7 ml

P2 : kelompok perlakuan sari daun cincau hijau 5,4 ml

Tabel 1 menunjukkan rerata asupan makan sampel sebelum dan selama perlakuan. Sebelum perlakuan, rerata asupan makan antar kelompok tidak memiliki perbedaan yang bermakna $(p=0,052)$. Selama perlakuan, terdapat perbedaan rerata asupan makan yang bermakna antara 
kelompok kontrol negatif dengan kelompok perlakuan sari daun cincau hijau $2,7 \mathrm{ml}$ dan $5,4 \mathrm{ml}$
( $p=0,031)$. Asupan makan seluruh kelompok terlihat mengalami peningkatan yang bermakna.

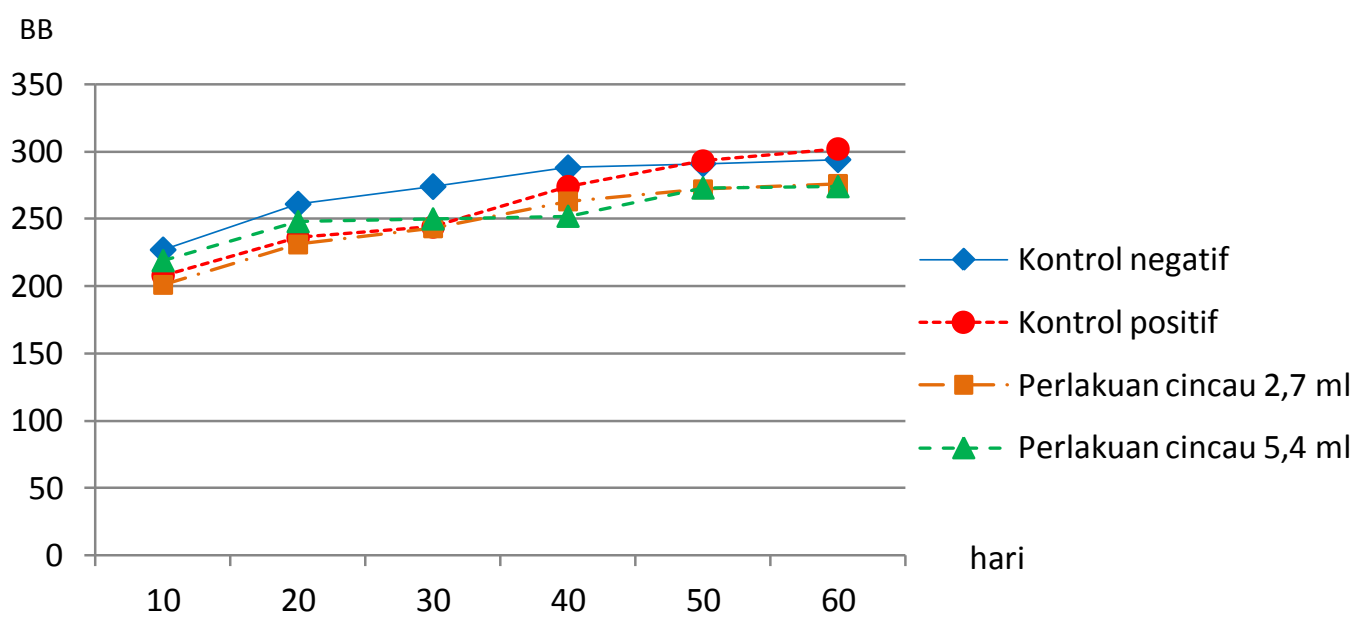

Gambar 2. Grafik Berat Badan

\section{Analisis Kadar Kolesterol HDL dan Kolesterol LDL}

Tabel 2. Hasil Analisis Kadar Kolesterol HDL

\begin{tabular}{|c|c|c|c|c|}
\hline \multirow[b]{2}{*}{ Kelompok } & \multirow[b]{2}{*}{$\mathbf{N}$} & Sebelum Perlakuan & Setelah Perlakuan & \multirow[b]{2}{*}{$P$} \\
\hline & & $\begin{array}{c}\text { Rerata }(\mathrm{SB}) \\
(\mathrm{mg} / \mathrm{dl})\end{array}$ & $\begin{array}{c}\text { Rerata (SB) } \\
(\mathrm{mg} / \mathrm{dl})\end{array}$ & \\
\hline $\mathrm{K}-$ & 7 & $25,7 \pm 4,57^{\mathrm{a}}$ & $26,4 \pm 4,83^{b}$ & 0,674 \\
\hline $\mathrm{K}+$ & 7 & $21,5 \pm 5,16^{\mathrm{a}}$ & $27,0 \pm 5,03^{\mathrm{b}}$ & 0,101 \\
\hline P1 & 7 & $25,3 \pm 2,29^{a}$ & $26,1 \pm 3,62^{b}$ & 0,439 \\
\hline $\mathrm{P} 2$ & 7 & $22,3 \pm 4,82^{\mathrm{a}}$ & $27,3 \pm 3,82^{b}$ & $0,028 *$ \\
\hline
\end{tabular}

${ }^{a}$ uji beda ANOVA $(\mathrm{p}>0,05)$

${ }^{b}$ uji beda Kruskal Wallis $(\mathrm{p}>0,05)$

*beda bermakna

Keterangan : K- : kelompok kontrol negatif

$\mathrm{K}+$ :kelompok kontrol positif

$\mathrm{P} 1$ : kelompok perlakuan sari daun cincau hijau 2,7 ml

P2 : kelompok perlakuan sari daun cincau hijau $5,4 \mathrm{ml}$

Tabel 2 menunjukkan bahwa kadar kolesterol HDL sebelum perlakuan antar kelompok tidak memiliki perbedaan yang bermakna $(p=0,213)$ begitu juga dengan setelah perlakuan $(\mathrm{p}=0,937)$. Seluruh kelompok terlihat mengalami peningkatan kadar kolesterol HDL, namun secara statistik kelompok perlakuan sari daun cincau hijau 5,4 ml mengalami peningkatan kadar kolesterol HDL yang bermakna $(\mathrm{p}<0,05)$.

Tabel 3. Hasil Analisis Kadar Kolesterol LDL

\begin{tabular}{|c|c|c|c|c|}
\hline \multirow[b]{2}{*}{ Kelompok } & \multirow[b]{2}{*}{$\mathbf{N}$} & Sebelum Perlakuan & Setelah Perlakuan & \multirow[b]{2}{*}{$\boldsymbol{P}$} \\
\hline & & $\begin{array}{c}\text { Rerata }(\mathrm{SB}) \\
(\mathrm{mg} / \mathrm{dl})\end{array}$ & $\begin{array}{c}\text { Rerata (SB) } \\
(\mathrm{mg} / \mathrm{dl})\end{array}$ & \\
\hline $\mathrm{K}-$ & 7 & $29,9 \pm 6,64^{\mathrm{a}}$ & $43,3 \pm 11,10^{\mathrm{a}}$ & $0,007 *$ \\
\hline $\mathrm{K}+$ & 7 & $32,9 \pm 9,62^{\mathrm{a}}$ & $43,1 \pm 13,14^{\mathrm{a}}$ & 0,110 \\
\hline P1 & 7 & $26,1 \pm 6,57^{\mathrm{a}}$ & $35,5 \pm 7,48^{\mathrm{a}}$ & $0,013 *$ \\
\hline P2 & 7 & $26,9 \pm 4,84^{\mathrm{a}}$ & $40,1 \pm 7,15^{\mathrm{a}}$ & $0,012 *$ \\
\hline
\end{tabular}

${ }^{a}$ uji beda ANOVA $(p>0,05)$ 
*beda bermakna

Keterangan : K- : kelompok kontrol negatif

$\mathrm{K}+$ :kelompok kontrol positif

P1 : kelompok perlakuan sari daun cincau hijau 2,7 ml

P2 : kelompok perlakuan sari daun cincau hijau 5,4 ml

Tabel 3 menunjukkan bahwa kadar kolesterol LDL sebelum perlakuan antar kelompok tidak memiliki perbedaan yang bermakna $(p=0,297)$ begitu juga dengan setelah perlakuan $(p=0,452)$. Kadar kolesterol LDL seluruh kelompok mengalami peningkatan. Kelompok kontrol negatif, perlakuan 1 dan 2 mengalami peningkatan kadar kolesterol LDL yang bermakna $(p<0,05)$.

\section{Analisis Perbedaan Perubahan Kadar Kolesterol HDL dan Kolesterol LDL}

Tabel 4. Hasil Analisis Perbedaan Perubahan Kadar Kolesterol HDL

\begin{tabular}{cccc}
\hline Kelompok & N & \multirow{2}{*}{$\begin{array}{c}\text { Rerata } \mathbf{~ H D L} \\
\text { (mg/dl) }\end{array}$} & $\boldsymbol{P}$ \\
\hline $\mathrm{K}-$ & 7 & $0,71 \pm 4,27$ & \\
$\mathrm{~K}+$ & 7 & $5,43 \pm 7,41$ & 0,134 \\
$\mathrm{P} 1$ & 7 & $0,86 \pm 2,73$ & \\
$\mathrm{P} 2$ & 7 & $5,00 \pm 3,05$ & \\
\hline
\end{tabular}

Keterangan : K- : kelompok kontrol negatif

$\mathrm{K}+$ :kelompok kontrol positif

$\mathrm{P} 1$ : kelompok perlakuan sari daun cincau hijau $2,7 \mathrm{ml}$

P2 : kelompok perlakuan sari daun cincau hijau $5,4 \mathrm{ml}$

Tabel 4 menunjukkan perbedaan bermakna antar kelompok perlakuan $(p=0,134)$. perubahan kadar kolesterol HDL dari sebelum Namun secara deskriptif peningkatan kadar hingga sesudah perlakuan. Hasil uji beda rerata kolesterol HDL tertinggi terdapat pada kelompok antar kelompok menunjukkan tidak terdapat kontrol positif. perbedaan peningkatan kadar kolesterol HDL yang

Tabel 5. Hasil Analisis Perbedaan Perubahan Kadar Kolesterol LDL

\begin{tabular}{cccc}
\hline Kelompok & $\mathbf{N}$ & $\mathbf{L D L}$ & $\boldsymbol{P}$ \\
\cline { 3 - 3 } & & $\begin{array}{c}\text { Rerata (SB) } \\
(\mathbf{m g} / \mathbf{d l})\end{array}$ & \\
\hline $\mathrm{K}-$ & 7 & $13,4 \pm 8,75$ & \\
$\mathrm{~K}+$ & 7 & $10,2 \pm 14,53$ & 0,629 \\
$\mathrm{P} 1$ & 7 & $9,4 \pm 7,21$ & \\
$\mathrm{P} 2$ & 7 & $13,3 \pm 9,81$ & \\
\hline
\end{tabular}

Keterangan : K- : kelompok kontrol negatif

$\mathrm{K}+$ :kelompok kontrol positif

$\mathrm{P} 1$ : kelompok perlakuan sari daun cincau hijau $2,7 \mathrm{ml}$

P2 : kelompok perlakuan sari daun cincau hijau 5,4 ml

Tabel 5 menunjukkan perbedaan perubahan kadar kolesterol LDL dari sebelum hingga sesudah perlakuan. Hasil uji beda rerata antar kelompok menunjukkan bahwa tidak terdapat perbedaan peningkatan rerata kadar kolesterol LDL yang bermakna antar kelompok perlakuan $(p=0,629)$.

\section{PEMBAHASAN}

\section{Asupan Makan dan Berat Badan Sampel}

Data asupan makan sampel didapatkan dari penimbangan sisa pakan setiap hari dengan jumlah pakan yang diberikan sebesar $20 \mathrm{~g}$. Sebelum perlakuan, rerata asupan makan antar kelompok tidak memiliki perbedaan yang 
bermakna secara statistik. Namun, kelompok kontrol negatif terlihat memiliki rerata asupan makan yang paling tinggi. Hal tersebut diduga karena perbedaan jenis pakan yang diberikan. Kelompok kontrol negatif mendapatkan pakan standar sedangkan kelompok lain mendapat pakan tinggi kolesterol.

Selama masa perlakuan, terdapat perbedaan rerata asupan makan yang bermakna antara kelompok kontrol negatif dengan kelompok perlakuan sari daun cincau hijau 2,7 $\mathrm{ml}$ dan 5,4 ml. Kelompok perlakuan sari daun cincau hijau 2,7 dan $5,4 \mathrm{ml}$ memiliki rerata asupan makan yang lebih rendah dibandingkan kelompok kontrol negatif. Hal tersebut disebabkan karena adanya tambahan asupan berupa sari daun cincau hijau yang diberikan kepada kelompok perlakuan sehingga sampel tidak mampu menghabiskan makanannya.

Jika dilihat dari perubahan asupan, seluruh kelompok mengalami peningkatan asupan makan yang bermakna. Peningkatan yang paling tinggi terdapat pada kelompok kontrol positif diikuti dengan kelompok kontrol negatif, kelompok perlakuan sari daun cincau hijau 2,7 $\mathrm{ml}$ dan 5,4 ml. Kelompok yang diberikan perlakuan sari daun cincau hijau terlihat mengalami peningkatan yang lebih rendah terutama kelompok dengan pemberian 5,4 ml. Hal tersebut dikarenakan kelompok perlakuan sari daun cincau hijau telah mendapat tambahan asupan sehingga mengurangi kapasitas lambung dalam menerima makanan yang menyebabkan sisa pakan menjadi lebih tinggi.

Selain menghitung asupan makan juga dilakukan pengukuran berat badan sampel setiap hari. Grafik pertumbuhan berat badan (Gambar 2) menunjukkan bahwa berat badan sampel mengalami peningkatan dari awal hingga akhir penelitian. Hal tersebut berbanding lurus dengan rerata asupan makan sampel yang meningkat.

\section{Pemberian Pakan Tinggi Kolesterol}

Pada penelitian ini untuk menginduksi dislipidemia pada tikus digunakan pakan tinggi kolesterol, yaitu pakan yang terdiri dari pakan standar ditambahkan kuning telur puyuh $10 \%$. Kuning telur puyuh dipilih karena mengandung kolesterol yang tinggi dibandingkan dengan kuning telur lain yaitu $2.139,17 \mathrm{mg} / 100$ g. ${ }^{18}$ Keadaan dislipidemia diketahui dengan cara membandingkan kadar kolesterol HDL dan kolesterol LDL tikus yang mendapat pakan tinggi kolesterol (kontrol positif, perlakuan sari daun cincau hijau 2,7 dan 5,4 ml) dengan kelompok kontrol negatif. Fungsi kelompok kontrol negatif adalah sebagai gambaran kadar kolesterol tikus normal.

Hasil analisis menunjukkan bahwa sebelum perlakuan atau setelah pemberian pakan tinggi kolesterol tidak terdapat perbedaan kolesterol HDL yang bermakna antar kelompok. Namun secara deskriptif, kelompok kontrol negatif memiliki kadar kolesterol HDL paling tinggi dibandingkan dengan kelompok lain, diikuti dengan kelompok perlakuan sari daun cincau hijau 2,7 ml. Hal tersebut bisa dikarenakan kelompok kontrol negatif hanya mendapat pakan standar yang tidak ditambah dengan kuning telur. Kadar kolesterol HDL yang juga tinggi pada kelompok perlakuan sari daun cincau hijau 2,7 ml walaupun sudah mendapat pakan tinggi kolesterol dapat disebabkan karena berat badan sampel pada kelompok tersebut lebih rendah dibandingkan dengan kelompok lain.

Kadar kolesterol LDL antar kelompok setelah pemberian pakan tinggi kolesterol tidak menunjukkan perbedaan yang bermakna. Kelompok kontrol positif memiliki rerata kadar kolesterol LDL yang paling tinggi dibandingkan dengan kelompok lain, diikuti dengan kelompok kontrol negatif, kelompok perlakuan sari daun cincau hijau $5,4 \mathrm{ml}$ dan $2,7 \mathrm{ml}$. Faktor yang mempengaruhi tingginya kadar kolesterol LDL pada kelompok kontrol positif belum diketahui. Karena jika dilihat dari asupan makan dan berat badan, kelompok ini memiliki rerata asupan dan berat badan yang lebih rendah dibandingkan dengan kelompok lain.

Tingginya kadar kolesterol LDL kelompok kontrol negatif dapat dipengaruhi oleh faktor berat badan sebelum perlakuan yang memiliki rerata paling tinggi dibandingkan dengan kelompok lain. Berat badan yang berlebih akan meningkatkan produksi lipoprotein yang mengandung LDL sehingga kadar kolesterol LDL menjadi tinggi. ${ }^{19}$

\section{Pengaruh Cincau Hijau terhadap Kadar Kolesterol HDL}

Sari daun cincau hijau diharapkan mampu meningkatkan kadar kolesterol HDL. Pada penelitian ini, kadar kolesterol HDL setelah perlakuan tidak menunjukkan adanya perbedaan yang bermakna antar kelompok. Kadar kolesterol HDL sebelum dan setelah intervensi pada seluruh kelompok mengalami peningkatan. Kelompok yang mengalami peningkatan kadar kolesterol HDL secara signifikan adalah kelompok perlakuan sari daun cincau hijau 5,4 ml yaitu sebesar $22 \%$. Hal ini sesuai dengan penelitian sebelumnya yang 
dilakukan pada kelinci dengan menggunakan ekstrak klorofil daun cincau hijau. ${ }^{8}$

Tingginya kadar kolesterol HDL pada kelompok perlakuan sari daun cincau hijau 5,4 ml dapat disebabkan karena asupan makan dan berat badan kelompok tersebut paling rendah dibandingkan dengan kelompok lain. Sari daun cincau hijau yang diberikan mengandung serat larut air yaitu pektin yang diduga mampu meningkatkan kadar kolesterol HDL dengan menghambat absorbsi asam empedu. Secara deksriptif, peningkatan kadar kolesterol HDL yang tinggi juga terjadi pada kelompok kontrol positif yang rerata asupan dan berat badannya paling tinggi dibandingkan dengan kelompok lain.

Selain faktor asupan makan dan berat badan, peningkatan kadar kolesterol HDL kemungkinan disebabkan karena adanya kenaikan apolipoprotein A dengan mekanisme yang belum diketahui dengan jelas. Apolipoprotein A merupakan protein pendukung terbentuknya HDL. Kolesterol HDL memiliki mekanisme tersendiri sehingga kadarnya lebih dipengaruhi oleh genetik dan jenis kelamin. ${ }^{6}$

\section{Pengaruh Cincau Hijau terhadap Kadar Kolesterol LDL}

Sari daun cincau hijau diharapkan mampu menurunkan kadar koleterol LDL. Pada penelitian ini menunjukkan kadar kolesterol LDL pada seluruh kelompok sebelum dan setelah intervensi mengalami peningkatan. Secara statistik, peningkatan yang bermakna terjadi pada kelompok kontrol negatif, kelompok perlakuan sari daun cincau hijau 2,7 ml dan 5,4 ml. Kelompok kontrol positif yang hanya mendapat pakan tinggi kolesterol justru mengalami peningkatan yang tidak bermakna.

Secara deskriptif, kelompok yang mengalami peningkatan kolesterol LDL paling rendah adalah kelompok perlakuan sari daun cincau hijau 2,7 ml. Jika dilihat dari masingmasing sampel, pada kelompok kontrol negatif terdapat satu sampel yang mengalami penurunan kadar kolesterol LDL, begitu juga dengan kelompok kontrol positif dan kelompok perlakuan sari daun cincau hijau 2,7 ml sedangkan kelompok perlakuan sari daun cincau hijau 5,4 ml tidak ada yang mengalami penurunan kadar kolesterol LDL.

Pada kelompok kontrol negatif, peningkatan kadar kolesterol LDL dapat dipengaruhi oleh bertambahnya umur dan berat badan sampel. Kelompok kontrol positif dan kelompok perlakuan cincau hijau yang mengalami peningkatan kadar LDL selain disebabkan karena bertambahnya umur dan berat badan juga dipengaruhi oleh asupan makanan tinggi kolesterol yang dikonsumsi.

Tidak adanya efek hipokolesterol dari sari daun cincau hijau yang diberikan bisa disebabkan karena telah terdegradasinya kandungan klorofil yang terdapat pada cincau hijau yang awalnya diduga dapat menurunkan kadar kolesterol LDL. Cincau hijau mengandung kadar klorofil total sebesar $21.5350 \mathrm{mg} / \mathrm{g}$, klorofil a $16.1200 \mathrm{mg} / \mathrm{g}$, dan klorofil b $5.4250 \mathrm{mg} / \mathrm{g}$. Klorofil merupakan senyawa yang mudah terdegradasi oleh panas, asam, cahaya, dan oksigen. Klorofil dan turunannya memiliki kapasitas antioksidan dan bioavailabilitas yang berbeda. Pada penelitian ini faktor yang dapat menyebabkan klorofil terdegradasi adalah cahaya dan oksigen. Karena pada penelitian ini menggunakan sari daun cincau hijau segar (klorofil alami) maka diduga pemberian klorofil tidak berpengaruh terhadap kadar kolesterol LDL sehingga tidak dapat mencegah peningkatan kadar kolesterol LDL yang disebabkan oleh pakan tinggi kolesterol.

Cincau hijau merupakan bahan pangan yang tinggi serat larut air. Namun pada penelitian ini peneliti belum dapat membuktikan efek serat dari cincau hijau terhadap penurunan kadar kolesterol LDL. Menurut teori serat dapat membantu menurunkan kadar kolesterol LDL dalam berbagai mekanisme yaitu memperlambat pengosongan lambung, mengganggu kerja enzim pencernaan, menghambat biosintesis kolesterol. ${ }^{20}$ Pada penelitian ini efek yang dapat dilihat secara langsung yaitu kelompok perlakuan sari daun cincau hijau 2,7 $\mathrm{ml}$ dan 5,4 ml memiliki rerata asupan makan yang lebih rendah dibandingkan dengan kelompok kontrol. Selain dikarenakan mendapat tambahan cincau hijau, hal ini juga berkaitan dengan kerja serat yang memperlambat pengosongan lambung sehingga sampel merasa kenyang dan tidak menghabiskan makanannya.

\section{KETERBATASAN PENELITIAN}

Keterbatasan penelitian ini adalah sampel belum berhasil dibuat dislipidemia serta tidak dilakukan pengujian kandungan serat pangan yang terdapat dalam sari daun cincau hijau sehingga tidak dapat diketahui seberapa besar peran serat larut air terhadap perubahan kadar kolesterol HDL dan kolesterol LDL.

\section{SIMPULAN}

Kadar kolesterol HDL antar kelompok perlakuan setelah dilakukan intervensi tidak 
terdapat perbedaan yang bermakna. Pemberian sari daun cincau hijau dengan dosis $5,4 \mathrm{ml}$ pada tikus mampu meningkatkan kadar kolesterol HDL tikus secara bermakna dari $22,29 \pm 4,82 \mathrm{mg} / \mathrm{dl}$ menjadi $27,29 \pm 3,82 \mathrm{mg} / \mathrm{dl}(\mathrm{p}<0,05)$.

Hasil uji beda rerata antar kelompok menunjukkan bahwa tidak terdapat perbedaan rerata kadar kolesterol LDL yang bermakna antar kelompok perlakuan $(p>0,05)$.

\section{SARAN}

Perlu dilakukan pengujian terhadap kandungan dan jenis serat pangan yang terdapat dalam sari daun cincau hijau untuk mengetahui besar pengaruh serat larut air terhadap kadar kolesterol LDL dan kolesterol HDL.

\section{DAFTAR PUSTAKA}

1. Gandy JW, Madden A, Holdsworth M, editors. Oxford Handbook of Nutrition and Dietetics. New York : Oxford University press ; 2006. p 460-461

2. Baraas F. Kardiologi Molekuler . Jakarta : Kardia Iqratama ; 2004. Hal. 250-251.

3. Nestel PJ. Management of Dyslipidaemia : Ecidence and Practical Recommendation. Australian Family Physician Vol 37. No.7 july 2008.

4. Sudijanto K. Dislipidemia di kota Padang, dll ; 2004

5. Gandha N. Hubungan Perilaku dengan Prevalensi Dislipidemia pada Masyarakat Kota Ternate tahun 2008. Universitas Indonesia ; 2009.

6. Botham KM, Mayes PA. Sintesin, Transpor, dan Eksresi Kolesterol. In : Murray RK, Granner DK, Rodwell VW. Biokimia Harper edisi 27 Jakarta : Penerbit Buku Kedokteran EGC ; 2006. P. 239249.

7. Widastuti D. Pemanfaaatan Daun Cincau Hijau sebagai Sumber Serat pada Mie Basah Berbasis Tepung Mokal. UNIKA ; 2010

8. Nurdin A, Khomsan S, Marliyati A, Clara MK. Pengaruh Pemberian Bubuk Ekstrak Cu-Turunan Klorofil Daun Cincau terhadap Profil Lipid Darah Kelinci. Media Gizi dan Keluarga, Juli 2008 Vol 32 No.1. Hal 104-113.

9. Artha N. Isolasi dan Karakterisasi Komponen Fungsional Pembentuk Gel Cincau Hijau (Cyclea barbata L, miers). [Disertasi]. Bogor : IPB ; 2001.

10. Gallaher D. Dietary Fiber and Its Physiological Effects. In Essentials of Functional Foods. An Aspen Publication. Maryland ; 2000 Pp. 273-292

11. Setiari N, Nurchayati Y. Eksplorasi Kandungan Klorofil Beberapa Sayuran Hijau sebagai Alternatif Bahan Dasar Food Supplement. BIOMA, Juni 2009. Vol. 11, No.1, hal. 6-10.
12. Limantara L. Daya Penyembuhan Klorofil. Malang: Ma Chung Press ; 2009. ISBN p.1-93.

13. Hidayat, A Aziz Alimul. Metode Penelitian Kesehatan. Surabaya : Health Books Publishing ; 2010.

14. Ismael S, Sastroasmoro S. Dasar-dasar Metodologi Penelitian Klinis. Jakarta : CV. Sagung Seto ; 2008.

15. Djam'an Q. Pengaruh Air Perasan Daun Cincau Hijau terhadap Konsentrasi HCL Lambung. Vol 1, No. 2, Juli-Desember 2009.

16. Ngatijan. Petunjuk Laboratorium, Metode Laboratorium, dalam Toksikologi. Pusat Antar Universitas Universitas Gajah Mada Yogyakarta ; 2006.

17. Smith JB, Mangkoewidjojo S. Pemeliharaan Hewan Percobaan di Daerah Tropis. Jakarta : Penerbit Universitas Indonesia ; 1988. Hal. 54-55

18. Dwiloka B. Efek Kolesterolemik berbagai Telur. Media Gizi \& Keluarga 2003 ; 27(2) : 58-65

19. Hoenig MR. Low Density Lipoprotein cholesterol is Inversely Correlated with Abdominal Visceral Fat Area. Biomed Central ; 2011. 10:12

20. Kritchevsky D. Dietary Fiber : Chemistry, Physiology, and Health Effects. New York : Plenum Press ; 1990 p. 173-175 